Misr J. Ag. Eng., 26(1): 132- 148

IRRIGATION AND DRAINAGE

\title{
MAXIMIZING WATER USE EFFICIENCY WITH SUBSURFACE DRIP IRRIGATION SYSTEM
}

\author{
Hosam A. M. Hiekal ${ }^{*}$
}

\section{ABSTRACT}

Accuracy of water application allows reducing average irrigation rate to a level that coincides with soil's hydraulic conductivity and minimizes percolation below the main root zone. Field experiment was conducted to confirm the efficiency of this approach, in a calcareous sandy clay loam soil. The source of irrigation water was ground shallow well. The treatments consisted of three irrigation systems (surface drip (TO) and subsurface drip (T15 and T30), and three levels of irrigation water application at 100,80 and 60\% of crop water requirements ( $T, 0.8 T$ and $0.6 T$, respectively). $16 \mathrm{~mm}$ drip lines with 0.33-m GR emitter spacing were placed on the furrow ridge surface in the middle of alternative plant rows. Laterals with the same characteristics were buried at two depths $(15$ and $30 \mathrm{~cm})$ in the subsurface drip irrigation (SDI). The obtained results indicated that the performance of the irrigation system was good throughout the cropping season. Values of statistical uniformity (SU) and distribution uniformity $(D U)$ were $94.8 \%$ and 0.93 , respectively. The moisture distribution in the soil monitored along plant growth stages indicated that SDI plots produced wider wetted patterns. Under scarce water, $(0.8 \mathrm{~T}$ and $0.6 T)$ the results demonstrated that SDI exceeded the surface drip irrigation in terms of potato yield and (IWUE). Maximum average yield (12.63 Mg/fed.) was recorded with subsurface drip line buried at $15 \mathrm{~cm}$ depth (T15). The overall average yield of potato in the surface drip laterals (TO) declined by 26.9 and $25.1 \%$ compared with SDI (T15) and (T30), respectively. As the applied water decreased from 2209 to $1496.5 \mathrm{~m}^{3} / \mathrm{fed}$. by using SDI, the average values of IWUE under SDI were higher than those obtained by surface drip irrigation at any level of applied irrigation water treatments. Thus, in the case of saving $20 \%$ of irrigation water, (0.8T15), the highest IWUE value $\left(8.913 \mathrm{~kg} / \mathrm{m}^{3}\right)$ was obtained. Meanwhile, the lowest value of IWUE $\left(4.178 \mathrm{~kg} / \mathrm{m}^{3}\right)$ was obtained by surface drip irrigation with 100\% water application amount level, (TO). This lowest value of IWUE may be reached to 50.5 and $51.7 \%$ compared with (T15) and (T30), respectively. In the same time, there was no significant effect for the level of water application on IWUE at (T), (0.8T) or (0.6T) treatments.

* Soil Cons. Dept., Desert Res. Center, Cairo, Egypt

Misr J. Ag. Eng., January 2009 
Keywords: Subsurface drip, deficient irrigation, soil moisture distribution, potato yield, irrigation water use efficiency.

\section{INTRODUCTION}

$\mathrm{W}$ ith increasing demands on limited water resources and the need to minimize adverse environmental consequences of irrigation, drip irrigation technology will undoubtedly play an important role in the future of the Egyptian agriculture. It provides many unique agronomic, water and energy conservation benefits that address many of the challenges facing irrigated agriculture. Application of uniform and sufficient water to seed for good crop establishment is one of the most challenge issues of subsurface drip irrigation (SDI), (Camp, 1998). A major concern with SDI is evaluation of its performance and measurement of uniformity parameters of its discharge. The performance of the SDI system should be quantified in relation to its design, management, operation and efficient use of water. Quantification allows the users to determine and control the dripper discharge, amount and timings of application of irrigation water so that the crop water requirements are met in a planned and effective manner (Thorburn et al., 2003 and Enciso et al., 2005). Estimation of uniformity coefficient for surface drip irrigation is easy but it is difficult in SDI system in which the laterals are buried below the soil surface. Various studies have rated most of the SDI systems as excellent on the basis of their performance (Ayars $e t$ al., 1999). Measurable indices of the degree of uniformity include coefficient of variation, CV (Wu, 1997), distribution uniformity, DU (Kruse, 1978) and statistical uniformity coefficient, SU (Bralts et al., 1981) were studied water infiltration in the SDI takes place in the region directly around the drippers, which is small compared with the total soil volume of irrigated field. A subsurface dripper usually forms a small cavity around it into which water can freely flow. Desired wetting patterns of soil can be obtained by selecting the appropriate dripper discharge and spacing (Lubana and Narda, 2001). Water distribution in the soil around a buried dripper mainly depends on soil texture, dripper discharge and root water uptake (Cote et al., 2003).

Potato is an important vegetable crop for Egypt with a production of more than 2,6 Million tons from approximately 200 thousand feddans (feddan $=0.42 \mathrm{ha}$ ) yearly (Ministry of Agriculture, 1999). Attaher et al., (2003) studied the performance of subsurface and surface drip irrigation systems and their effects on the yield of potato. They found that, with surface drip irrigation, the soil moisture content decreased gradually in the horizontal direction and reached field capacity at a 
distance of 25 and $30 \mathrm{~cm}$ from the T-Tape and GR emitters, respectively. The moisture content was higher than field capacity with SDI by up to 22 and $25 \%$ near the T-Tape and GR emitters, respectively, in the horizontal direction, and throughout $30 \mathrm{~cm}$ in the vertical direction. The total yield was not significantly affected by the level of irrigation but was significantly affected by the drip irrigation system. The highest yield $(13.8 \mathrm{Mg} / \mathrm{fed}$.) was obtained with the T-Tape surface drip system as combined with the highest water use efficiency "WUE" $\left(12.4 \mathrm{~kg} / \mathrm{m}^{3}\right)$. Kang et al. (2002) indicated that under application of total crop evapotranspiration (ETc), little difference was found among different irrigation frequency.

Previous researches showed that the yield and quality of potatoes can improved through drip irrigation (Abdel-Ati, 1998; and Sabra, 2000), while other older research (Islam et al., 1990) indicated significant tuber yield and size reductions with the reduction of applied water, but they also pointed out significant differences among genotypes in response to water stress. The potato crop evapotranspiration vary from 30.0 to $70.0 \mathrm{~cm}$, depending on the environment and crop growth stages (Shock and Feibert, 2000). Onder et al., (2005) reported that farmers should not be advised to grow potato under water deficiency of more than $33 \%$ of the irrigation water requirements.

The present experiment was conducted mainly to study the influence of subsurface drip irrigation on the yield of potato under calcareous sandy clay loam soil conditions. The specific objectives of this study were (1) to evaluate the performance of SDI system, (2) to study the effect of different application levels of irrigation water on the yield of potato; and the irrigation water use efficiency, (IWUE) and (3) to determine the optimal depth of drip line on the basis of shape and arrangement of the wetting zone beneath it.

\section{MATERIALS AND METHODS}

\section{Location and soil properties of the experiment site:}

A field experiment was carried out during winter season of 2004/2005 at Maryot Experiment Station of Desert Research Center ( $\left.31^{\circ} 00^{\prime} 44^{\prime \prime} \mathrm{N}-29^{\circ} 47^{\prime} 41^{\prime \prime} \mathrm{E}\right)$, Alexandria Governorate. Some physical and chemical properties of the soil at the experimental site, are shown in Tables (1 and 2). The soil of the experimental site was deep, well-drained calcareous sandy clay loam in texture and non-saline. 
Table (1): Some soil physical properties of the experimental site.

\begin{tabular}{|c|c|c|c|c|c|c|c|c|c|}
\hline \multirow{2}{*}{$\begin{array}{c}\text { Soil } \\
\text { depth } \\
(\mathrm{cm}) \\
\end{array}$} & \multicolumn{4}{|c|}{ Particle size distribution (\%) } & \multirow{2}{*}{$\begin{array}{l}\text { Hydraulic } \\
\text { Cond. } \\
(\mathrm{cm} / \mathrm{h})\end{array}$} & \multirow{2}{*}{$\begin{array}{c}\text { Bulk } \\
\text { Density } \\
\left(\mathrm{g} / \mathrm{cm}^{3}\right) \\
\end{array}$} & \multirow{2}{*}{$\begin{array}{l}\text { F.C. } \\
\text { (V\%) }\end{array}$} & \multirow{2}{*}{$\begin{array}{l}\text { P.W.P } \\
(\mathrm{V} \%)\end{array}$} & \multirow{2}{*}{$\begin{array}{c}\text { Av. } \\
\text { Water } \\
\text { (V \%) }\end{array}$} \\
\hline & $\begin{array}{c}\text { Coarse } \\
\text { Sand }\end{array}$ & $\begin{array}{l}\text { Fine } \\
\text { Sand }\end{array}$ & Silt & Clay & & & & & \\
\hline $0-15$ & 24.51 & 31.8 & 22.8 & & & 1.4 & 21.72 & 8.01 & 13.71 \\
\hline $15-30$ & 23.65 & 32.06 & 22.70 & 21.59 & 2.45 & 1.47 & 20.76 & 7.61 & 13.1 \\
\hline
\end{tabular}

Table (2): Some soil chemical properties of the experimental site.

\begin{tabular}{|c|c|c|c|c|c|c|c|c|c|c|c|}
\hline $\begin{array}{c}\text { Soil } \\
\text { depth }\end{array}$ & $\begin{array}{c}\mathrm{CaCo}_{3} \\
(\%)\end{array}$ & $\mathrm{pH}$ & $\begin{array}{c}\mathrm{EC} \\
(\mathrm{dS} / \mathrm{m})\end{array}$ & \multicolumn{4}{|c|}{$\begin{array}{c}\text { Soluble Cations } \\
(\mathrm{meq} / \mathrm{l})\end{array}$} & \multicolumn{3}{c|}{$\begin{array}{c}\text { Soluble Anions } \\
(\mathrm{meq} / \mathrm{l})\end{array}$} \\
\cline { 5 - 13 } & & & & $\mathrm{Ca}^{++}$ & $\mathrm{Mg}^{++}$ & $\mathrm{Na}^{+}$ & $\mathrm{K}^{+}$ & $\mathrm{CO}_{3}{ }^{-}$ & $\mathrm{HCO}_{3}{ }^{-}$ & $\mathrm{Cl}^{-}$ & $\mathrm{SO}_{4}{ }^{-}$ \\
\hline \hline $0-15$ & 26.20 & 7.42 & 2.85 & 6.68 & 3.89 & 18.74 & 1.59 & - & 4.46 & 21.49 & 4.95 \\
\hline $15-30$ & 27.47 & 7.36 & 2.37 & 10.53 & 2.25 & 10.2 & 1.03 & - & 2.73 & 12.4 & 8.88 \\
\hline
\end{tabular}

\section{Irrigation system installation and experimental treatments:}

The experiment was carried out in a split plot design with three replicates. Irrigation system including three lateral depths at $0,15.0$ and $30.0 \mathrm{~cm}$ were namely, surface drip irrigation (T0); sub surface drip irrigation (T15); and (T30), respectively, used as the main plots. Each main plot was $891 \mathrm{~m}^{2}(27 \times 33 \mathrm{~m})$ divided into three equal subplots representing three levels of irrigation water namely, 100, 80 and $60 \%$ of crop water requirements (denoted as T, 0.8T and $0.6 \mathrm{~T}$, respectively). Each sub plot $(9 \times 33 \mathrm{~m})$ represented 9 ridges $(1 \mathrm{~m} \times 33 \mathrm{~m})$. The number of drip lines was three for each treatment, and every treatment was replicated three times at random procedure. Whole tubers of potato (Solanum tuberosum L.) cv. Sponta were sown on October $1^{\text {st. }}, 2004$ at the depth of $10 \mathrm{~cm}$ in the raised ridges (furrows), spaced at $30 \mathrm{~cm}$ apart on both sides of drip lines ( 7 plants $/ \mathrm{m}^{2}$ on an average).

Installation of the irrigation systems was carried out in September 2004. Each subplot had one valve, one pressure gauge and one flow meter to control the applied irrigation water volume. Control head facilities included double sand media filters; double disk filters, fertilizer injector, main flow meter and other safety tools. Drip lines were installed and buried manually at depths of 0.0, 15.0, and $30.0 \mathrm{~cm}$ in the middle of ridges. Care was taken to lay the drip lines straight on the center of the ridges. The hydraulic characteristics of installed drip system are given in Table (3). The source of irrigation water was under ground shallow well, and the water salinity was $2.01 \mathrm{dS} / \mathrm{m}$ as an average through the crop season.

Misr J. Ag. Eng., January 2009 
Table (3): Some hydraulic characteristics of the drip irrigation system.

\begin{tabular}{|l|c|}
\hline \multicolumn{1}{|c|}{ Characteristic } & Description \\
\hline Wall thickness, $\mathrm{mm}$ & 1.12 \\
\hline Inner diameter, $\mathrm{mm}$ & 13.75 \\
\hline Operating pressure, bar & 1.05 \\
\hline Flow rate per 1 m length, lph & 11.81 \\
\hline Spacing between two drippers, $\mathrm{m}$ & 0.33 \\
\hline Spacing between two laterals, $\mathrm{m}$ & 1.0 \\
\hline Depth of drip line, $\mathrm{cm}$ & 0,15, and 30 \\
\hline
\end{tabular}

\section{Soil moisture content:}

Neutron probe scattering was calibrated and used for measuring the soil water content. Three PVC access tubes were placed in each treatment (one for each replicate). Access tubes were pressed at the center of the row to a depth of 1.20 $\mathrm{m}$. Measurements of soil moisture content (volumetric) in all treatments were started at depth of $0.3 \mathrm{~m}$ from ridge surface with increments of $0.15 \mathrm{~m}$ till $1.05 \mathrm{~m}$ to follow the soil moisture at $1^{\text {st. }}, 2^{\text {nd. }}, 3^{\text {rd. }}$ and $4^{\text {th. }}$ growth stages of potato crop, directly before and after one day of irrigation events. At the same time, soil samples were collected using soil auger sampler from six points $20 \mathrm{~cm}$ apart and perpendicular to the drip lateral, selected randomly from each treatment to determine soil moisture distribution from drip line gravimetrically. Sampling was started at ridge surface down to $1.05 \mathrm{~m}$ with increment of $0.15 \mathrm{~m}$ and soil moisture was calculated on volumetric basis (Garcia, 1978). Subsequent samples were taken $1 \mathrm{~m}$ down from the previous sample location.

The soil profiles at each soil sampling location were subdivided into a network of $(15 \mathrm{~cm}$ by $20 \mathrm{~cm})$ rectangular shapes, Fig. (1). Soil moisture contour maps were made using the SURFER Mapping System 8.0, it was selected as the girding method since this approach is one of the most flexible and useful methods available for almost any type of data sets (Golden Software, 2002).

\section{Estimation of water uniformity for drip irrigation system:}

There are five micro irrigation uniformity classifications, ranging from excellent to unacceptable, were recognized by the American Society of Agricultural Engineers (ASAE, 1999). In this study tests for uniformity of water distribution by drip system were carried out according to the method described by Kruse (1978) and Bralts et al. (1981). 


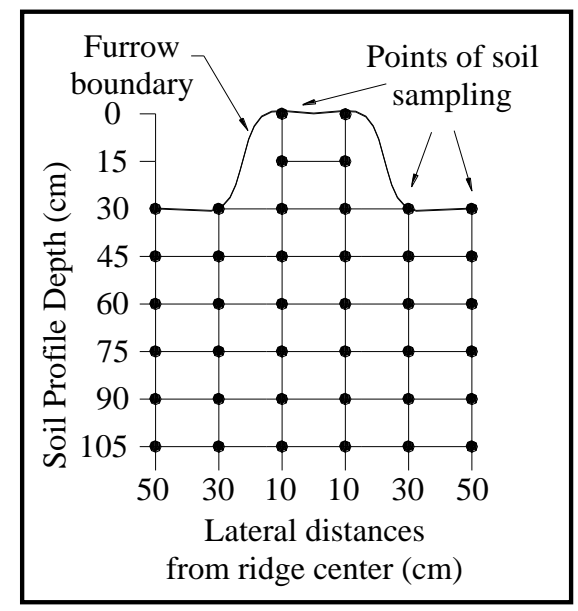

Fig. (1): Network shows the locations of soil sampling for measurements of moisture content.

The uniformity of water application was calculated in terms of coefficient of variation $(\mathrm{CV})$, distribution uniformity (DU) and statistical uniformity (SU) using the following equations:

$$
\begin{aligned}
& C V=\left(\frac{S d}{q}\right) \\
& D U=\left(\frac{q_{l q}}{q}\right) \\
& S U=\left(1-\frac{S d}{q}\right) \times 100
\end{aligned}
$$

Where: $\mathrm{Sd} \quad=$ the standard deviation of drippers' discharge (lph);

$\mathrm{q}=$ the mean dripper flow rate (lph); and

$\mathrm{q}_{\mathrm{lq}}=$ the mean lowest quarter drippers discharge (lph).

\section{Estimation of water requirements and irrigation schedule:}

The irrigation water was applied in order to raising the soil moisture content to field capacity according to the plant water requirements and the stored soil moisture content. Potato root system is relatively sparse; approximately $85 \%$ of the root length is concentrated in the upper $30 \mathrm{~cm}$ of the soil layer (Kang et al., 2002), as well as, the irrigation water was applied when soil moisture indicated a deficit of $50-55 \%$ of available moisture content at $30 \mathrm{~cm}$ downward ridge surface with $20 \mathrm{~cm}$ perpendicular to the drip lateral. 
For each irrigation treatment, the amount of irrigation water was calculated according to the equation given by Israelsen and Hansen (1962).

$$
E T_{c}=I+P \pm \Delta S-R-D
$$

Where: $\mathrm{ET}_{\mathrm{c}} \quad=$ crop evapotranspiration $(\mathrm{mm})$;

I = irrigation amount (mm);

$\mathrm{P} \quad=$ precipitation $(\mathrm{mm})$;

$\Delta \mathrm{S} \quad=$ change of soil water storage $(\mathrm{mm})$;

$\mathrm{R} \quad=$ surface runoff ( $\mathrm{mm}$ ); and

$\mathrm{D} \quad=$ deep percolation below crop root zone $(\mathrm{mm})$.

Since the precipitation in the growing season was small, the deep percolation and surface runoff could be ignored under drip irrigation, therefore, the irrigation amount was estimated using the field balance equation as follow:

$$
I=E T_{c} \pm \Delta S
$$

Weather data were collected from an automatic weather station located in Maryot Experiment Station. Reference crop evapotranspiration $\left(\mathrm{ET}_{\mathrm{o}}\right)$ was calculated using Penman-Monteith's formula and methodology formulated by Allen et al. (1998) for irrigation scheduling. Potato is about 120 day duration crop and may be divided into four stages namely initial: 20 days, developmental: 30 days, middle: 40 days and tuber maturity: 30 days; as well as, the crop coefficient was taken as 0.75, 0.85, 1.15 and 0.75, respectively, Dorrenbos and Pruitt (1977).

\section{Nutrient management:}

The application of farmyard manure compost was applied uniformly at the rate of $20 \mathrm{~m}^{3} /$ fed. during soil preparation, and followed by recommended potassium (as potassium sulphate); phosphorus (as triple super phosphate) and nitrogen (as ammonium nitrate) fertilizers at the rate of 50;150; and $120 \mathrm{~kg} / \mathrm{fed}$., respectively, (Abdel-Ati, 1998). In all treatments, neither diseases were noticed throughout the crop season nor insecticides and fungicides were applied.

\section{Potato yield:}

Harvesting potato was started manually after 125 day from sowing. Yield samples of potato tubers from each treatment and its replications were recorded. Standard analysis of variance (ANOVA) was used to evaluate the effects of the treatments on the yield and to determine the significance of the main treatments and its interaction with subtreatments. Least significance differences (LSD) test 
was used for comparing between the main treatments and subtreatments according to Snedecor and Cochran, (1982).

\section{Irrigation water use efficiency (IWUE):}

IWUE was determined according to James (1988) as follow:

$$
I W U E=\frac{Y}{W_{a}}
$$

Where: IWUE $=$ irrigation water use efficiency, $\mathrm{kg} / \mathrm{m}^{3}$,

$\mathrm{Y} \quad=$ crop yield, $\mathrm{kg} / \mathrm{fed}$., and

$\mathrm{W}_{\mathrm{a}} \quad=$ total applied water, $\mathrm{m}^{3} / \mathrm{fed}$.

Data were statistically analyzed according to Snedecor and Cochran, (1982).

\section{RESULTS AND DISCUSSIONS}

\section{Performance of the irrigation system:}

Evaluation of the performance parameters of the installed irrigation system at the beginning of the experiment indicated that the coefficient of variation $(\mathrm{CV})$ of flow rates was 0.052 , which means a good performance of the system. Decroix and Malaval (1985) had concluded that a CV between 0.05 and 0.066 indicated a good performance of the drip system. Average values of statistical uniformity (SU) and distribution (DU) were 94.77\% and 0.93, respectively. According to Pitts (1997), SU and DU greater than $90.0 \%$ and 0.87, respectively, implies an excellent functioning of the drip system.

\section{Amounts of irrigation water applied:}

Values of irrigation water requirements and water applied during different growth stages of potato crop, for different treatments were determined (Tables, 5 and 6). The water requirements of crop depends on the actual crop evapotranspiration were varied from 3.87 to $4.08 \mathrm{~mm} /$ day at the early stage to the peak demand period, (Table 5). The total depth of irrigation water needed for potato crop was estimated under the experiment conditions as $41.2 \mathrm{~cm} / \mathrm{season}$. SDI saved irrigation water compared with surface drip irrigation. 32.2 percent of irrigation water saved by using SDI at high soil moisture depletion 0.6T. The differences in applied irrigation water between SDI and surface drip treatments may be attributed to: 1) the exceeding amounts with surface drip treatments for leaching some salts were noticed above soil surface after rainfall events. 2) SDI treatments were good distribution moisture uniformity and less evaporation losses from the upper soil layer compared with surface drip treatments.

Misr J. Ag. Eng., January 2009 
Table (5) Irrigation water requirements at different stages of potato crop.

\begin{tabular}{|c|c|c|c|}
\hline \multicolumn{4}{|c|}{$\begin{array}{l}\text { Irrigation water requirements at different growth stages } \\
\text { of crop ( } \mathrm{mm} / \text { day) }\end{array}$} \\
\hline $\begin{array}{l}\text { Initial } \\
\text { (20 day) }\end{array}$ & $\begin{array}{c}\text { Development } \\
\text { (30 day) }\end{array}$ & $\begin{array}{l}\text { Middle } \\
\text { (40 day) }\end{array}$ & $\begin{array}{l}\text { Maturity } \\
\text { (30 day) }\end{array}$ \\
\hline 3.87 & 2.84 & 3.17 & 4.08 \\
\hline
\end{tabular}

Table (6) Irrigation water applied $\left(\mathrm{m}^{3} / \mathrm{fed}\right.$.) for growth stages of potato crop under different treatments and water saving (\%) by SDI.

\begin{tabular}{|c|c|c|c|c|c|c|c|c|c|}
\hline \multirow[t]{2}{*}{$\begin{array}{c}\text { Crop growth } \\
\text { stage }\end{array}$} & \multicolumn{3}{|c|}{$\begin{array}{c}\text { Surface drip } \\
\text { treatments }\end{array}$} & \multicolumn{3}{|c|}{$\begin{array}{l}\text { Subsurface drip } \\
\text { treatments }\end{array}$} & \multicolumn{3}{|c|}{$\begin{array}{c}\text { Water saving due } \\
\text { to SDI }(\%)\end{array}$} \\
\hline & $\mathbf{T}$ & $0.8 \mathrm{~T}$ & 0.6 & $\mathbf{T}$ & $0.8 \mathrm{~T}$ & $0.6^{\prime}$ & $\mathbf{T}$ & $0.8 \mathrm{~T}$ & $0.6 \mathrm{~T}$ \\
\hline & 62 & & & & & & & & \\
\hline & 5 & & & & & & & & \\
\hline & 527.6 & & 4 & 305 & 2 & 190.3 & & .4 & 40.6 \\
\hline & 532.6 & & 340.2 & 395. & & 250.3 & & 25.9 & 26.4 \\
\hline$n$ & 2209.1 & $\overline{752.5}$ & 181400.2 & 14966.5 & 1213.2 & 4951.0 & 32 & 30.8 & 32.2 \\
\hline
\end{tabular}

\section{Soil moisture distribution:}

Soil moisture distributions patterns (V\%) particularly after one day of irrigation events at different growth stages of potato, with $100 \%$ of water requirements at irrigation treatments (T0, T15 and T30) are shown in Figs. (2 through 4). Those layouts were arrangement with dimensions of ridge furrow cross sections as well as dripline depth. During the early growth stage, when tuber formation had not started, $10.0-15.0 \mathrm{~cm}$ depth of soil was approximately at field capacity. Therefore, the soil surface under the dripper evidently wetted in case of surface drip line (T0) treatment (Fig. 2).

In the case of subsurface drip with laterals depth of $15.0 \mathrm{~cm}$ (T15), the soil water content (V\%) at the surface varied from 12.5 to $14.5 \%$ at different growth stages of crop (Fig. 3). At this depth of lateral position, water moved upwards keeping the surface soil dry at different stages of potato with adequate amount of soil moisture (avg. 18.0\%) as wetted soil bulb of $20.0 \mathrm{~cm}$ in width by $30.0 \mathrm{~cm}$ depth, which was very beneficial for good tuber formation resulting in higher yield in treatment T15. 

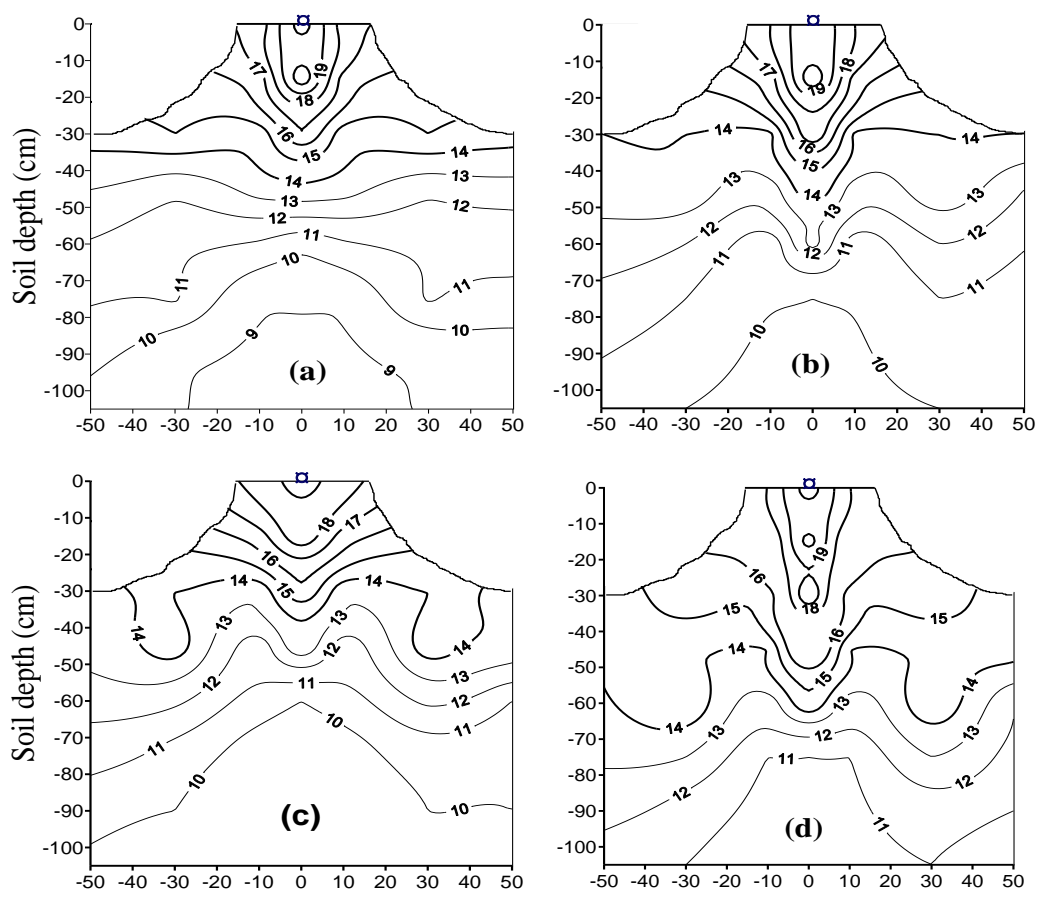

Fig. (2): Soil moisture (V\%) in the case of surface drip line treatment (T0) at Init. (a); Dev. (b); Mid. (c); and Mat. (d) growth stages of potato crop.
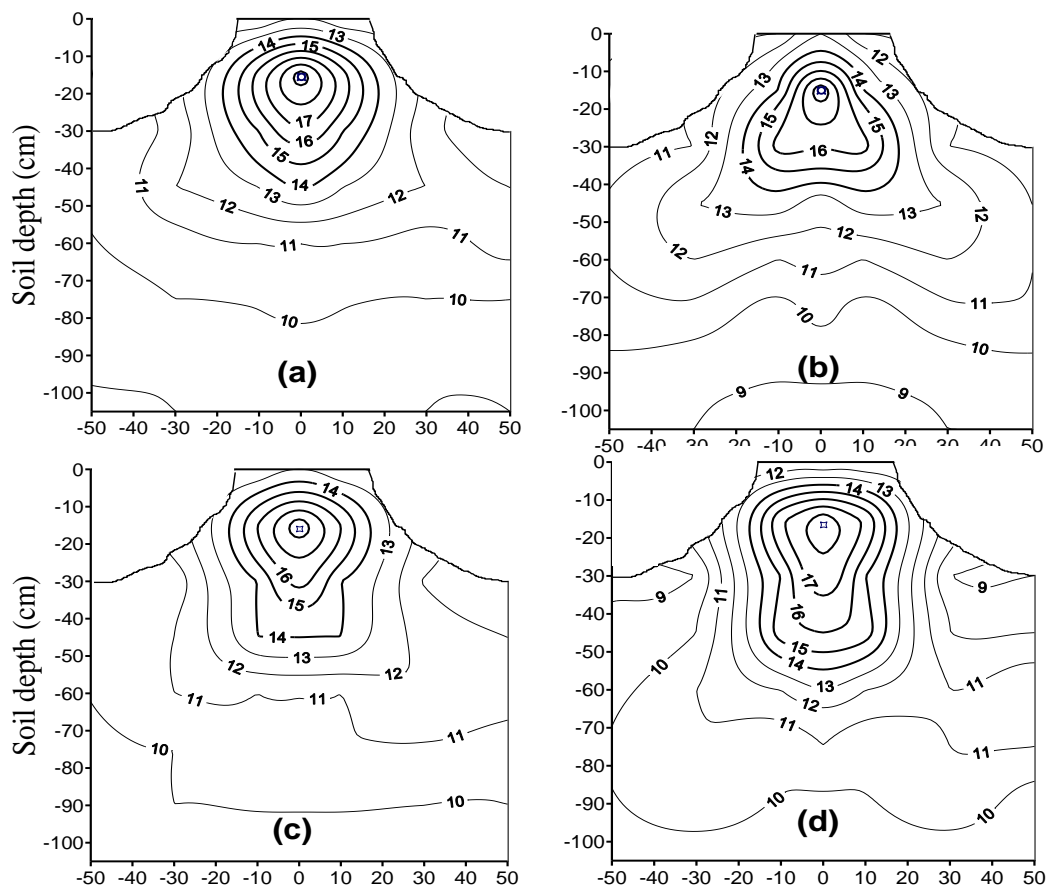

Fig. (3): Soil moisture (V\%) in the case of subsurface drip line treatment (T15) at (a); Dev. (b); Mid. (c); and Mat. (d) growth stages of potato crop. 
In the case of subsurface drip with laterals depth of $30.0 \mathrm{~cm}$ (T30) (Fig. 4), the upward capillary movement of water was not sufficient and soil moisture content at the surface decreased (avg. 13.5\%) comparing with treatments of T0 and T15, residual soil moisture conditions was observed (more than 16\% of vol. soil moisture adjacent the laterals) under the laterals at depths between 15 and 50 $\mathrm{cm}$, it were more abroad and became deeper than the other drip line treatments in all growth stages of the crop (Fig. 4).
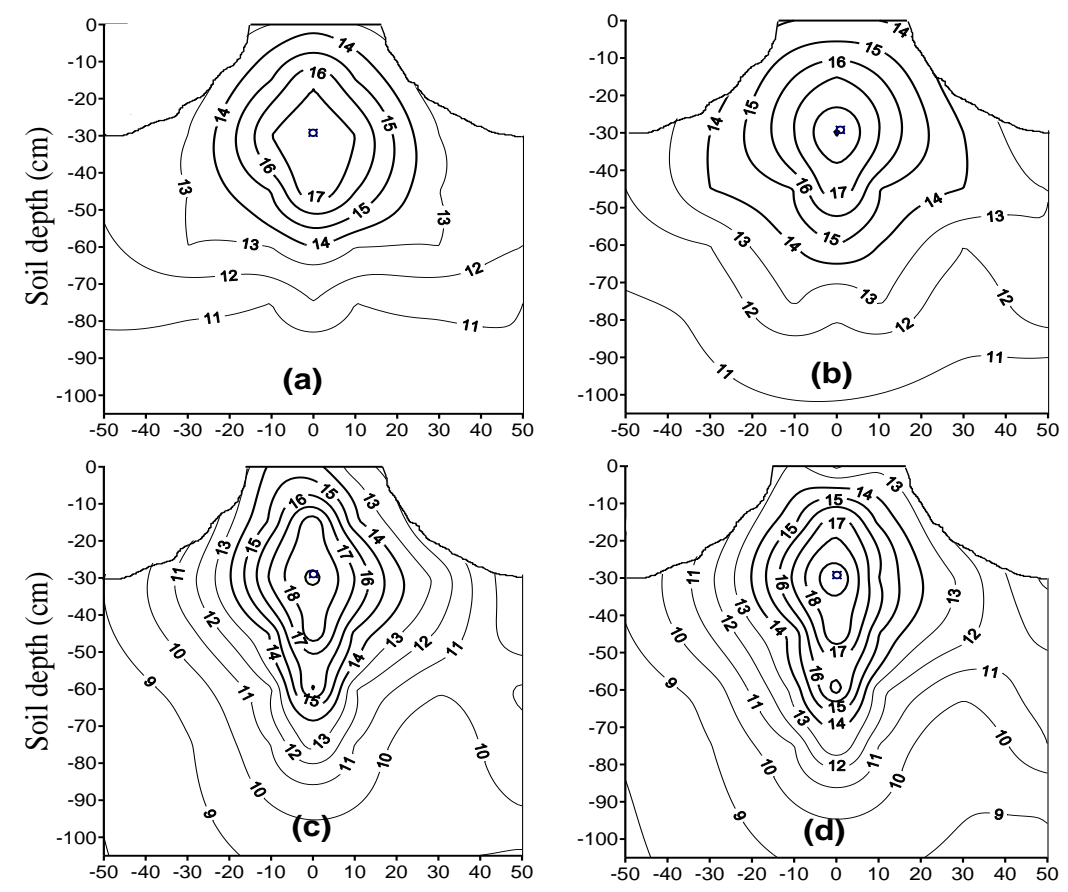

Fig. (4): Soil moisture (V\%) in the case of subsurface drip line treatment (T30) at (a); Dev. (b); Mid. (c); and Mat. (d) growth stages of potato crop.

The results indicated that as the drip line depth increased, the dry zone started from soil surface became better than surface drip (T0). Also, adequate amount of moisture was still available in the region of the plant roots and better moisture transmission to the surrounding soil and keeps on replenishing the crop root zone. Therefore, keeping the drip line within the crop root zone and sufficiently below the soil surface replenishes the root zone effectively due to prevention surface moisture evaporation losses and restriction of upward capillary flow, similar results were obtained by Yuan et al., (2003). 


\section{Effect of drip line depth on potato yield:}

The effect of drip line depth had significant effect on the yield of potato, Table (7). Maximum yield of potato was recorded in treatment $\mathrm{T} 15$ (12.63 Mg/fed.) with applying $100 \%$ of irrigation water requirements, the increments were 26.9 and $2.4 \%$ compared with $\mathrm{T} 0$ and $\mathrm{T} 30$ treatments, respectively. The average yield of potato in treatment $0.8 \mathrm{~T} 15$ was $10.813 \mathrm{Mg} / \mathrm{fed}$. with increments 43.4 and $5.6 \%$ compared with $0.8 \mathrm{~T} 0$ and $0.8 \mathrm{~T} 30$ treatments, respectively. While, the average yield of potato in treatment $0.6 \mathrm{~T} 15$ was $8.123 \mathrm{Mg} / \mathrm{fed}$. with increments 32.0 and $16.1 \%$ compared with $0.6 \mathrm{~T} 0$ and $0.6 \mathrm{~T} 30$ treatments, respectively.

It is recommended to achieve higher yields, that drip line should be buried at $15.0 \mathrm{~cm}$ depth. Similar types of results were reported by Shock and Feibert (2000), where they observed that reduction in total yield of potato due to the progressive deficit irrigation treatments averaged $6.7,10$ and $14 \%$ with corresponding water savings of 25.0, 36.0 and $40.0 \%$.

\section{Effect of irrigation levels on potato yield:}

Yield of potato were significantly affected between all used treatments (Table 7), which demonstrated that the application of 100,80 and $60 \%$ of irrigation water levels had significantly affected on potato yield $(\mathrm{P}<0.05)$.

With applying $100 \%$ of irrigation water requirements by T0 treatment obtained $9.229 \mathrm{Mg} / \mathrm{fed}$., the declines in yield reached to 22.4 and $50.0 \%$ by $0.8 \mathrm{~T} 0$ and 0.6T0 treatments, respectively. Meanwhile, applying T15 treatment obtained the highest yield value $12.63 \mathrm{Mg} / \mathrm{fed}$., the declines reached to 55.5 and $16.8 \%$ by $0.6 \mathrm{~T} 15$ and $0.8 \mathrm{~T} 15$ treatments, respectively. In the meantime, applying T30 treatment obtained $12.328 \mathrm{Mg} / \mathrm{fed}$., the declines reached to 76.2 and $20.4 \%$ by $0.6 \mathrm{~T} 30$ and $0.8 \mathrm{~T} 30$ treatments, respectively.

It was realistic that, $20 \%$ reduction of irrigation water can be saved by $0.8 \mathrm{~T} 15$ treatment with 14.4 and $12.3 \%$ reduction in potato yield compared with T15 and T30 treatments, respectively, and the increments reached to 5.6, 17.2 and $43.4 \%$ in potato yield compared with $0.8 \mathrm{~T} 30, \mathrm{~T} 0$ and $0.8 \mathrm{~T} 0$, respectively. While applying $60 \%$ of water level using $0.6 \mathrm{~T} 15$, potato yield declined by 35.7, 24.9, 20.7 and $12.0 \%$ compared with $\mathrm{T} 15,0.8 \mathrm{~T} 15,0.8 \mathrm{~T} 30$ and $\mathrm{T} 0$ treatments, respectively, and the increments reached to $32.0,16.1$ and $7.8 \%$ in potato yield compared with $0.6 \mathrm{~T} 0,0.6 \mathrm{~T} 30$ and $0.8 \mathrm{~T} 0$, respectively. These results are in agreement with that obtained by Hegney and Hoffman (1997), which shown that potato yield responds linearly to applied water. 
Table (7) Potato yield (Mg/fed.) and IWUE $\left(\mathrm{kg} / \mathrm{m}^{3}\right)$ as affected by irrigation water levels and depths of drip lines treatments.

\begin{tabular}{|c|c|c|c|}
\hline $\begin{array}{c}\text { Irrigation drip } \\
\text { line depth }\end{array}$ & $\begin{array}{c}\text { Applied } \\
\text { irrigation } \\
\text { water level }\end{array}$ & $\begin{array}{c}\text { Average Yield } \\
\text { (Mg/fed.) }\end{array}$ & $\begin{array}{c}\text { Average } \\
\text { IWUE (kg/m }\end{array}$ \\
\hline \hline \multirow{3}{*}{ T0 } & 1.0 & 9.229 & 4.178 \\
\cline { 2 - 4 } & 0.8 & 7.538 & 4.301 \\
\cline { 2 - 4 } & 0.6 & 6.151 & 4.393 \\
\hline \multirow{3}{*}{ T15 } & 1.0 & 12.630 & 8.440 \\
\cline { 2 - 4 } & 0.8 & 10.813 & 8.913 \\
\cline { 2 - 4 } & 0.6 & 8.123 & 8.541 \\
\hline \multirow{3}{*}{ T30 } & 1.0 & 12.328 & 8.238 \\
\cline { 2 - 4 } & 0.8 & 10.243 & 8.443 \\
\cline { 2 - 4 } & 0.6 & 6.995 & 7.355 \\
\hline \hline \multicolumn{3}{|c|}{ LSD (P < 0.05) } \\
\hline Applied Irrig. water level & 0.000 & n.s \\
\hline Drip line depth & 0.014 & 0.000 \\
\hline Water level \& Drip line depth & 0.000 & 0.000 \\
\hline
\end{tabular}

\section{6. Irrigation water use efficiency (IWUE):}

The average values of IWUE are shown in Table (7). Treatment $0.8 \mathrm{~T} 15$ gave the highest average value $\left(8.913 \mathrm{~kg} / \mathrm{m}^{3}\right)$ of IWUE, the average values obtained with SDI were higher than those with surface drip irrigation at all the applied irrigation water levels. Thus, saving of 20.0 and $40.0 \%$ of irrigation water with burying the drip line at $15.0 \mathrm{~cm}$ depth had significantly affected the mean values of IWUE under the experiment conditions. Meanwhile, the surface position of drip laterals, (T0) gave the lowest average value $\left(4.178 \mathrm{~kg} / \mathrm{m}^{3}\right)$ of IWUE, it was doubled or mostly doubled with T15 and T30, respectively. In the same time, nosignificant effect for the saving of irrigation water neither $20 \%$ nor $40 \%$ under the same depth of drip lines on the average IWUE. These results are in agreement with that obtained by Kashyap and Panda (2003); and Onder et al. (2005), who observed similar findings for potato crop with less amount of applied irrigation water, which gave the highest IWUE.

\section{SUMMARY AND CONCLUSIONS}

On the basis of low coefficient of variation (CV) of dripper flow rates within of 0.052 , it may be concluded that the performance of the drip system was good throughout the cropping season. The values of statistical uniformity (SU) and distribution uniformity (DU) were found $94.77 \%$ and 0.93 , respectively. Soil 
moisture content pattern at different growth stages of potato at different treatments was monitored. With subsurface drip irrigation (SDI), the soil surface remains relatively dry and soil moisture content increased at the $30.0 \mathrm{~cm}$ soil depth at all growth stages of crop and water moves beyond the ridge base. Potato tuber yield was higher under SDI system than under surface drip irrigation system. The highest average yield was $12.63 \mathrm{Mg} / \mathrm{fed}$., it recorded by applying $100 \%$ of crop water requirements under sub surface drip irrigation at $15 \mathrm{~cm}$ depth (T15) treatment and the lowest value was $6.151 \mathrm{Mg} / \mathrm{fed}$., by applying $60 \%$ of crop water requirements with surface drip irrigation (0.6T0) treatment. Potato yield was significantly affected by the depth of drip line and maximum yield was obtained by applying $100 \%$ of water requirements $\left(1496.5 \mathrm{~m}^{3} / \mathrm{fed}\right.$. of irrigation water) and by placing the drip line at $15.0 \mathrm{~cm}$ soil depth. Treatment $0.8 \mathrm{~T} 15$ gave maximum irrigation water use efficiency (IWUE), it was $8.91 \mathrm{~kg} / \mathrm{m}^{3}$. IWUE was higher by SDI than surface drip irrigation (mostly doubled) under the experiment conditions. It could be recommended that for reducing weed infestation and maximizing both yield and its IWUE, it would be suitable in large-scale farms to use drip lines buried at $15.0 \mathrm{~cm}$ depth under similar conditions of newly reclaimed desert land in Egypt.

\section{REFERENCES}

Abdel-Ati, Y. Y. (1998), Yield and quality of potato as affected by phosphorus, chicken manure and seed tuber size. Assiut J. Agric. Sci., 29 (5): 129-147.

Allen, R. G.; L. S. Pereira; D. Raes; and M. Smith (1998). Crop evapotranspiration. Guidelines for computing crop water requirements. FAO Irrigation and Drainage. Paper No. 56, FAO, Rome, Italy

ASAE, (1999). Soil and Water Terminology. S 526.1. ASAE Standards. ASAE, St. Joseph, MI, USA

Attaher, S. M.; M. A. Medany; A. A. A. Aziz; M. M. Mostafa; and A. F. AbouHadid (2003). Energy requirements and yield of drip-irrigated potato. In Proceedings of the International Symposium on the Horizons of Using Organic Matter and Substrates in Horticulture, Cairo, Egypt, 6-9 April, 2002. Acta-Hort., No.608: 191-198.

Ayars, J. E.; C. J. Phene; R. B. Hutmacher; K. R. Davis; R. A. Shoneman; S. S. Vail; and R. M. Mead (1999). Subsurface drip irrigation of row crops: a review of 15 years of research at the Water Manag. Lab. Agric. Water Manag., 42 (1): 1-27. 
Bralts, V. F.; I. P. Wu; and H. M. Gitlin (1981). Manufacturing variation and drip irrigation uniformity. Trans. ASAE, 24: 113-119.

Camp, C. R. (1998). Subsurface drip irrigation: a review. Trans. ASAE, 41 (5): 1353-1367.

Cote, C. M.; K. L. Bristow; P. B. Charlesworth; F. J. Cook; and P. J. Thorburn (2003). Analysis of soil wetting and solute transport in subsurface trickle irrigation. Irrig. Sci., 22: 143-156.

Decroix, M.; and A. Malaval (1985). Laboratory evaluation of trickle irrigation equipment for field system design. In: Proc. $3^{\text {rd }}$ Int. Drip/trickle Irrig. Cong., vol. I, Fresno, Cal., ASAE, 1: 325-338.

Dorrenbos, J.; and W. O. Pruitt (1977). Crop water requirements. FAO Irrig. and Drain. Paper 24:156p. Rome.

Enciso, J.; J. Jifon; and B. Wiedenfeld (2005). Subsurface drip irrigation of onions: Effects of emitter spacing and drip depth on yield. ASAE Annual Int. Meeting, Paper: 052242, Tampa, Florida, 17 - 20 July. USA.

Garcia, I. (1978). Soil water laboratory manual, Dept. Agric. and Chem. Eng., Colorado State U., Fort Collins, Colo., USA.

Golden Software Inc. (2002). A powerful contouring, gridding, and surfacemapping package for scientists and engineers Ver. 8. Golden Software Inc., Golden, Colo. 80401-1866, USA.

Hegney, M. A., and H. P. Hoffman (1997). Potato irrigation-development of irrigation scheduling guidelines. Horticulture Res. and Develop. Corp. Proj. NP. 6, Western Australia, Dept. of Agric.W. Australia, Australia. 114p.

Islam, T.; H. Sarker; J. Alam; and H. U. Rashid (1990). Water use and yield relationships of irrigated potato. Agric. Water Manag., 18: 173-179.

Israelsen, O. W.; and V. E. Hansen (1962). Irrigation principles and practices. $3^{\text {rd }}$ Ed., Willey and Sons., NY., USA.

James, L. G. (1988). Principles of farm irrigation system design. Jone Willey \& Sons (Ed.), N Y, pp. 543.

Kang, Y.; F. X. Wang; S. P. Liu; and J. Lou (2002) Effects of drip irrigation frequency on soil wetting pattern and root distribution of potato in North China Plain. In Proc. ASAE, Annual Int. Meeting/VX CIGR World Congr. ASAE Paper: 022282, St. Joseph, Mich, USA.

Kashyap, P. S.; and R. K. Panda (2003). Effect of irrigation scheduling on potato crop parameters under water stressed conditions. Agric. Water Manag., 59 (1): 49-66. 
Kruse, E. G. (1978). Describing irrigation efficiency and uniformity. J. Irrig. Drain., 104 (IR 1): 34-41.

Lubana, P. P. S.; and N. K. Narda (2001). Modeling soil water dynamics under trickle emitters - a review. J. Agric. Eng. Res., 78: 217- 232.

Ministry of Agriculture and Land Reclamation of Egypt (1999). Central Admin. of Agric. Economics: 213-215. Egypt.

Onder, S.; M. E. Caliskan; D. Onder; and S. Caliskan (2005). Different irrigation methods and water stress effects on potato yield and yield components. Agric. Water Manag., 73 (1): 73-86.

Pitts, D. J. (1997). Evaluation of micro irrigation systems. South West Florida Research and Education Center, Florida U., USA.

Sabra, F. S. (2000). Population dynamics of potato weeds under three types of irrigation in newly reclaimed desert land in Egypt. Alex. J. Agric. Res., 45 (1): 193-205.

Shock, C. C.; and E. B. G. Feibert (2000). Deficit irrigation of potato. Deficit Irrigation Pract., Water Reports 22, ISBN 92-5- 104768-5, 109 pp.

Snedecor, G. W. and W. G. Cochran (1982). In "Statistical Methods". $7^{\text {th }}$ Ed. Iowa State Univ. Press, Ames, USA. Pp 593.

Thorburn, P. J.; F. J. Cook; and K. L. Bristow (2003). Soil-dependent wetting from trickle emitters: implications for system design and management. In Micro-irrigation: Advances in system design and manag., Irrig. Science J., 22 (3-4): $121-127$.

$\mathrm{Wu}$, I. P. (1997). An assessment of hydraulic design of micro-irrigation systems. Agric. Water Manag., 32 (3): 275-284.

Yuan, B. Z.; S. Nishiyama; and Y. Kang (2003). Effects of different irrigation regimes on growth and yield of drip-irrigated potato. Agric. Water Manag., 63 (3): $153-167$.
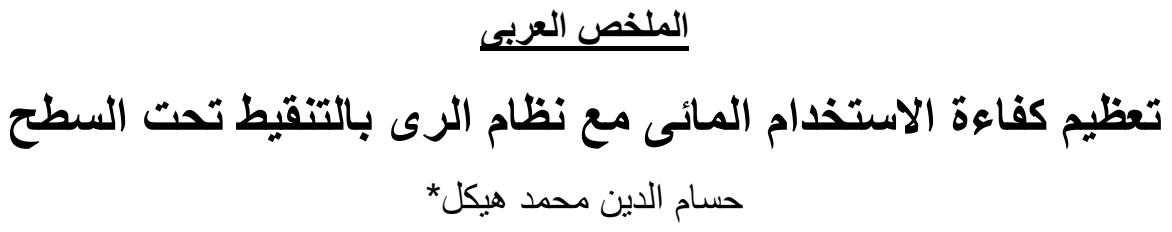

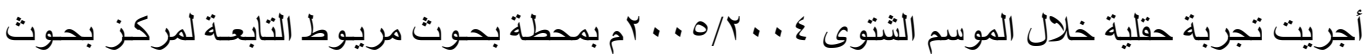

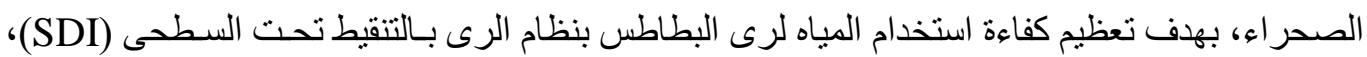

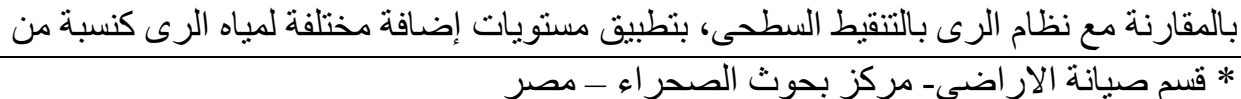


الاحتياجات المائية للمحصول. وكانت التربة جيرية ذات قوام رملى طميي، ومصدر الميـاه بئر سطحى.

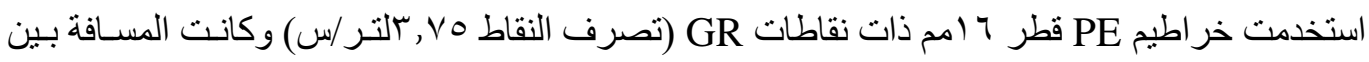

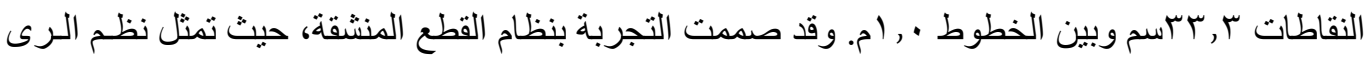

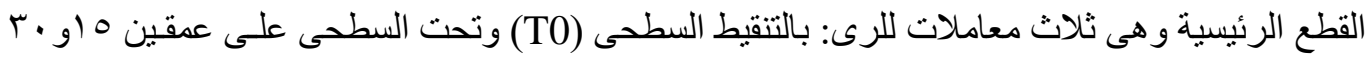

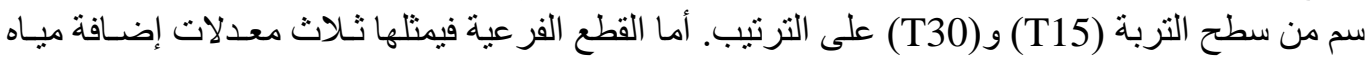

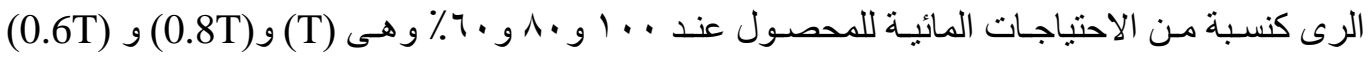

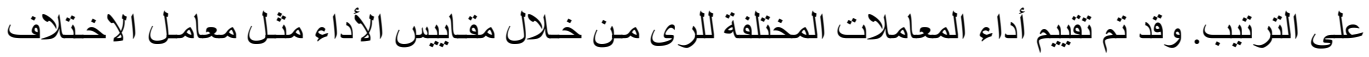

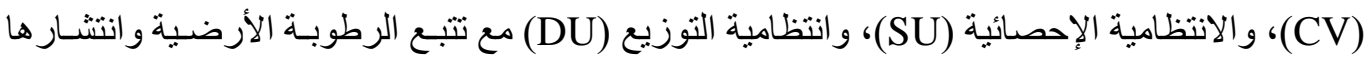

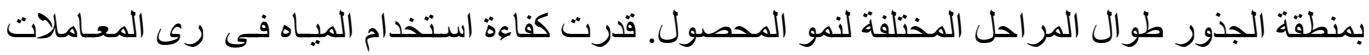

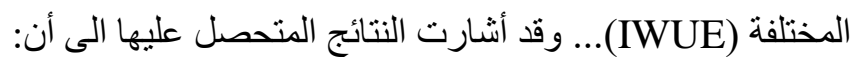

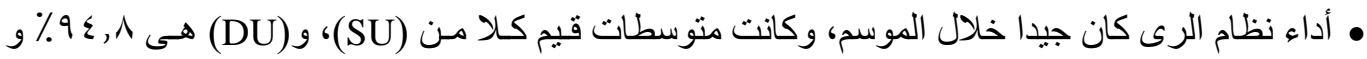

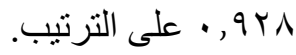

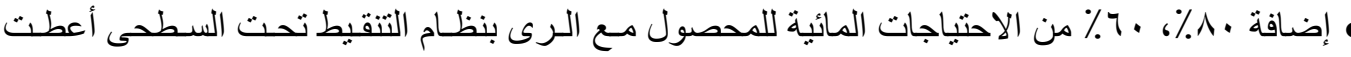

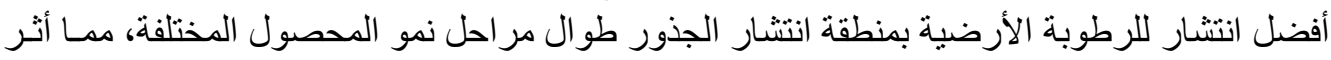

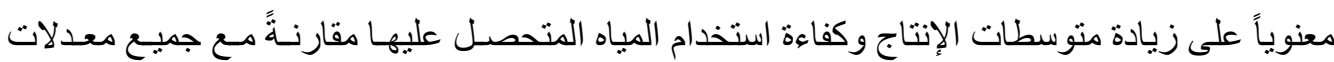

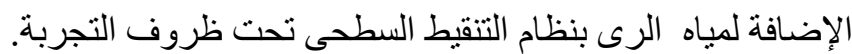

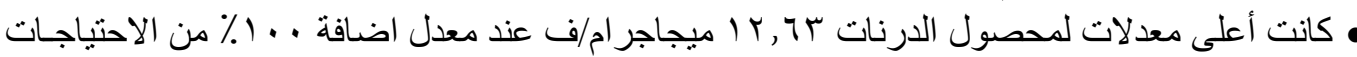

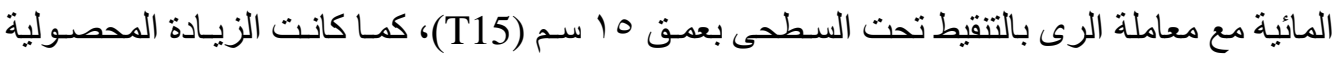

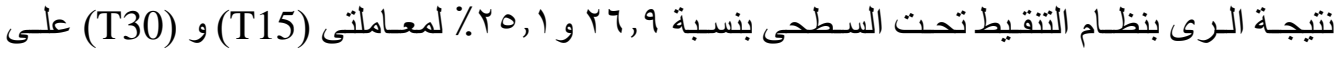

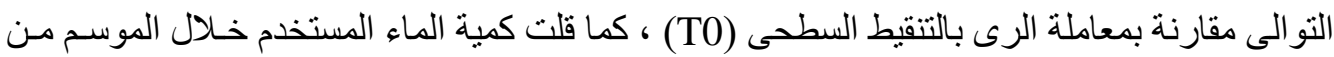

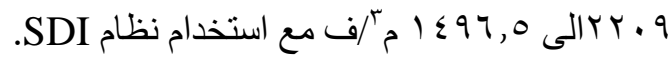

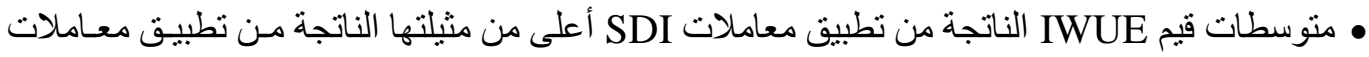

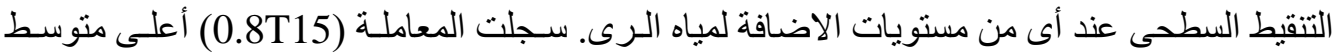

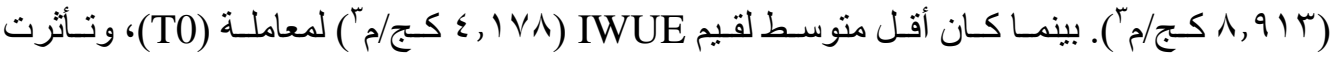

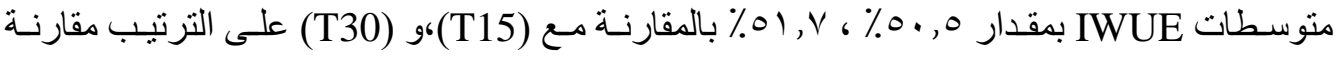

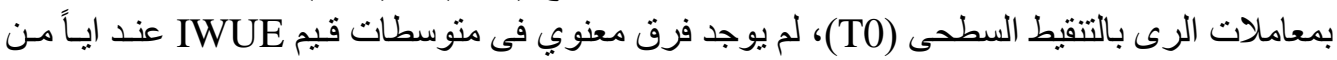

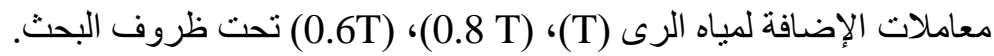

